\title{
SETTING OFFER PRICES BY HOUSING DEVELOPERS - SELECTED ISSUES IN THE LIGHT OF LITERATURE REVIEW
}

\author{
Iwona Dittmann, PhD \\ Faculty of Finance \\ University of Economics in Wroctaw \\ e-mail: iwona.dittmann@ue.wroc.pl
}

\begin{abstract}
This paper deals with selected theoretical issues pertaining to the setting of asking prices by housing developers. Determinants of the buyer's and seller's reservation prices have been identified. The advantages and disadvantages, in terms of behavioral economics, of the pricing strategies practiced by housing developers have been indicated. The strategy based on fixing an asking price roughly equal to the estimated market value of the property was compared with the strategy based on offering an inflated asking price (with the assumption of price negotiations). A second comparison concerned the strategy of price disclosure compared with the strategy of price non-disclosure.

The reflections contained within the article were based on behavioral economics and marketing theory. The discussion was based largely on foreign articles, observed examples of pricing policy carried out by housing developers in Poland, and information obtained from housing developers and real estate brokers who are active on the primary market.
\end{abstract}

Key words: housing market, developer, pricing strategy.

JEL Classification: C78, D44, R32.

Citation: Dittmann I., 2014, Setting offer prices by housing developers - selected issues in the light of the literature studies, Real Estate Management and Valuation, vol. 22, no. 4, pp. 17-26.

DOI: $10.2478 /$ remav-2014-0033

\section{Introduction}

Price is one of the most important criteria taken into account by potential home buyers. At the same time, selling prices, as well as incurred costs, determine a developer's profits, and the time-frame of the sale influences his financial liquidity. The topic of pricing strategy and tactics encompasses a wide array of issues. These are issues concerning, among others, the methods of fixing the asking price, discount policy, price competition, the anchoring heuristic in property valuation, and the relationship between the asking price and the time-span of the transaction. Resolutions to these issues can be found in the theories of: microeconomics (e.g. issues of: price elasticity of demand, utility), finance, cost accounting, marketing, management and also behavioral economics.

Issues tied in with pricing strategies in the case of transactions on the residential real estate-market are widely described in foreign literature. It should be noted that, in general, these issues concern a transaction between an occasional seller, who is not a developer, and a buyer, with the participation of a real estate agent. There are significant differences between an occasional seller and a developer. First of all, in contrast to the one-time seller selling his house or residence, the developer sells many identical or similar residences at the same time. If his competitive position is strong enough on the given local market, he can, to some degree, dictate the conditions of the transaction, including the price. This occurs less frequently in the case of an individual sale of a residence or home. Moreover, 
a developer's activity usually occurs with reference to the long-term perspective. The developer makes decisions (including pricing decisions) that are not only short-term decisions, but also longterm or strategic ones (concerning, i.a. liquidity, surviving and competing on the market, company development, financial resources). On the other hand, the similarities between the developer and the occasional seller should also be highlighted. The goal of both entities is to sell at the highest possible price and in the shortest possible time-frame. As a constant and professional market participant, the developer can have greater experience in setting asking prices and negotiating (resulting from multiple transactions).

It appears that one could attempt to apply some of the conclusions reached by foreign researchers concerning home sales to the sales of accommodation by a developer. The goal of the article is to present the issue of setting asking prices by real-estate developers as well as to undertake an attempt at indicating the advantages and disadvantages of selected pricing strategies taken by real-estate developers in the context of behavioral economics.

\section{Pricing strategies of companies and methods of setting the asking price}

Pricing strategy can be defined as "a set of decisions concerning problems associated with prices on the given product market, arranged in a logical whole, within which management takes into account the subsequent stages of decision making, in accordance with the marketing conception of price: a calculation of the basic price and adaptation of the basic price to market conditions," (KARASIEWICZ 1997).

It should be emphasized that the choice of a pricing strategy is largely determined by the strategic goal of the business, which can be, i.a.: 1) achieving target profits; 2) strengthening the position on the market; 3) managing demand; 4) closing the way for competitors, catching up with or following them; 5) developing a product or company image; 6) stabilizing prices (RUSKIN-BROWN 2009). For this reason, the choice of pricing strategies depends to a great degree on the current competitive position of the company (being, e.g. the result of branding), the type of competition (e.g. stable competition), barriers to entry, market characteristics (e.g. an oligopoly), current market conditions (e.g. demand exceeding supply), the stage of market development (e.g. an emerging market), and the number of products for sale (the size of the investment, in the case of a developer). Thus, pricing strategy constitutes a part of marketing strategy, and price is one of four elements of the marketing-mix.

The following classical marketing pricing strategies have been described in literature:

- penetration pricing: a strategy of low prices, helping the company to enter a new market

- premium pricing: a strategy of high prices, reflecting the high quality of the product (premium segment); used most often in markets, where price is seen as indicative of quality, the goal is to strengthen the quality image of the product,

- creaming or skimming: is based on two stages: initially premium pricing and then the gradual lowering of the price in order to forestall competition or other market pressures (or as a reaction to them),

- promotional pricing: a strategy of lowering prices in connection with a discount or promotion and then returning to prior price levels,

- linear pricing: a strategy reflecting the position of the product (with regards to the quality or buyer's status) within the seller's assortment,

- bait pricing: a strategy based on the low price of the standard product (in order to allow the client to enter a given market) and additional costs for additions to the basic product,

- multiple pricing: consists of selling the same product at different prices in different markets,

- predatory pricing: is based on using very low prices and has as its goal the elimination of competition (in the form of dumping, it may be forbidden by law),

- limit pricing: has as its goal making the new market unattractive to competition, by setting very low prices from the beginning,

- value-based pricing: consists of setting the price of products or services based on their value from the point of view of the consumer, the goal is long-term cooperation with the customer (RUSKIN-BROWN 2009).

In the case of housing developers in Poland, the use the first five of these classical marketing strategies can be observed.

The available literature indicates three groups of methods for setting asking prices. These are methods: 1) based on costs; 2) based on demand; 3) based on the price of competitors' products. It 
ought to be emphasized that although these groups are treated as independent, when making pricing decisions one should not settle on a single method, but combine ones from different groups. Most companies adopt one of the methods as their basic method, and treat the remainder as supplementary methods, utilized for price correction (WANIOWSKI 2003). According to studies led by Waniowski, businesses most frequently turn to cost methods as their basic method (51\%), with demand methods $(25 \%)$ and competitors' price-based methods $(24 \%)^{1}$ being employed less often. The results of research conducted in Europe in the 90's indicate an even clearer dominance of cost-based methods; they constituted the basis of price accounting in $81 \%$ of the cases. Of the remaining $19 \%$, the clear majority used systems based on the general level of competitors' prices (59\%), with others making use of customer reaction studies $(21 \%)$, consultation with retailers $(9 \%)$, imitation of the leader $(8 \%)$ and others (3\%) (per: RUSKIN-BROWN 2009). No research concerning the methods used by real-estate developers, especially those working on the Polish market, appears to have been conducted.

\section{Types of prices on the real-estate market and their determinants}

In real-estate turnover we can indicate four types of prices: 1) asking (offer, listed) price, 2.) seller's reservation price, 3) buyer's reservation price, and 4) transaction price (sale price). They have been presented, along with the subsequent linkages between them, in figure 1. Additionally, we can estimate market value, which is indicated by the most probable price of the property ${ }^{2}$. The asking price is fixed by the seller and declared to the potential buyers. It can be negotiable or non-negotiable. The seller's reservation price is the lowest price, which he or she is willing to accept. Analogously, the buyer's reservation price is the highest price, which he or she is willing to pay. The seller does not disclose his or her reservation price to the buyer. And vice versa, the buyer would rather not disclose his or her reservation price to the seller (cf. HOROWITZ 1992).

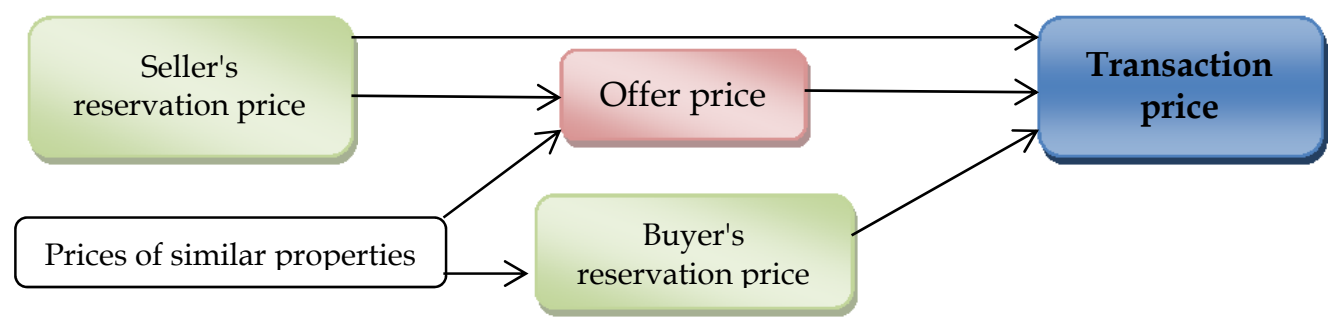

Fig. 1. Types of prices along with the linkages between them. Source: own work.

If we denote: $P_{L}$ - asking (listed) price, $P_{R S}$ - seller's reservation price, $P_{R B}$ - buyer's reservation price, $\mathrm{P}_{\mathrm{A}}$ - transaction price, we can determine that:

1) $P_{L} \geq P_{A}$, which means that the asking price is a sort of "price ceiling", which excludes the possibility of the sale of the property at a higher price ${ }^{3}$ (HOROWITZ 1992),

2) $P_{L} \geq P_{R S}$, which means, that the highest possible seller's reservation price is equal to the asking price designated by him (HOROWITZ 1992),

3) $P_{R S} \geq P_{A} \geq P_{R B}$, (by definition).

Keeping in mind the last relationship, it can be determined that the transaction price will fluctuate between the seller's reservation price and the buyer's reservation price. We can pose questions about: 1) the determinants of the range limits, i.e. of the seller's reservation price and the buyer's reservation price; 2) the possibility of estimating the buyer's reservation price by the seller; 3) factors which influence the specific value of the transaction price in the range specified by this relationship.

In response to the first question, it should be noted that a property will be acquired at the price which the buyer is willing to pay. The amount which the buyer is willing to pay depends, as it

\footnotetext{
1 Surveys conducted in the year 2000, covering 133 businesses.

2 Possible to be attained on the market, determined while taking into account the transaction prices after accepting the following assumptions: 1) the parties to the agreement were independent of each other, they did not act in a compulsory situation and had a firm intention to conclude the agreement; 2) the time necessary to display the property on the market and to negotiate the terms of the agreement had passed (Real Estate Management Act). 3 Theoretically there is a possibility that a low asking price will cause a so called "stampede" which will invoke an auction resulting in a transaction price higher than the asking price ("bidding war"). The profitability of this strategy on the real estate market has not, however, been empirically confirmed (BUCCHIANERI, MINSON 2013).
} 
appears, firstly on his financial limitations (stemming from the savings he possesses, banks' lending policies, creditworthiness) ${ }^{4}$; Secondly, it depends on the price of similar properties. Assuming that the buyer behaves rationally, it should be recognized that he will not pay more than what he would pay for a similar property. We can thus assume that the buyer will "estimate" the investment value ${ }^{5}$ of the given property, assessing it according to his own needs and comparing it to the characteristics and prices of other properties. Does the buyer, however, perform such a strict estimation? It should be acknowledged that the majority of residential real estate buyers purchase housing for their own use rather than for investment purposes. Therefore, they can set the reservation price unwittingly, after analyzing the asking prices of selected properties on the local market. They can also, especially in the case of limited financial means, conduct an initial selection of properties based on price, and choose the property from this limited selection which best suits their individual needs (no longer comparing them based on price). It appears that buyers can also conduct an initial selection based on location (e.g. close to work, family). In such cases it is difficult to ascertain that they are establishing a specific investment value of the given property. Thirdly, if the buyer is purchasing the property for investment purposes, the maximum transaction price is the price which assures the required return on investment ${ }^{6}$. The required return rate can result from, inter alia, the return rate capable of being reached from alternative investments with a similar risk level. The seller, on the other hand, will be willing to sell the property for a price which allows for a return of the costs as well as making a profit (unless, due to other goals such as maintaining financial liquidity or investments on other markets, he lowers the reservation price). The above mentioned determinants have been compiled in Table 1.

Table 1

Determinants of the reservation price

\begin{tabular}{lll}
\hline \multicolumn{1}{c}{ buyer } & \multicolumn{1}{c}{ seller } \\
\hline$-\quad$ prices of similar properties, & $-\begin{array}{l}\text { cost of building (plus the required } \\
\text { profit margin) }\end{array}$ \\
$-\quad$ individual preferences, & \\
$-\quad$ banks' lending policies (LTV, DTI, margins), & \\
$-\quad$ market rents (as an alternative to purchasing an apartment, \\
$\quad$ or if the buyer has an investment purpose), \\
$-\quad$ return rate on alternative investments.
\end{tabular}

Source: own elaboration.

In response to the second question (can the seller estimate the buyer's reservation price), if we assume that the buyer's reservation price depends on the individual preferences and financial capabilities of the particular buyer, then it should be recognized that the seller is not capable of estimating this value. The seller can only estimate the market value of the property, thus the objective value, for the average buyer on the given local market. He or she can determine this value using an income approach (buyer-investor can rent out the residence) as well as a comparative approach (the buyer will compare competitors' offers).

Among the factors which influence the specific value of the transaction price, that is the location in the given range (closer to the seller's reservation price or closer to the buyer's reservation price), it seems we can indicate both factors which are independent of the seller (market conditions, e.g. a buyers' market) as well as factors dependent on the seller (e.g. position on the local market, brand). The asking price will, of course, have a fundamental effect on the transaction price. In theoretical considerations of this issue, Yavas and Yang conclude that the choice of asking price by the property seller depends on his estimation of the property's market value, his bargaining power, the commission for the agent, costs of finding a buyer and the shape of the function describing the relationship

\footnotetext{
4 Polish developers are, as it seems, aware that a bank's credit policy affects the effective demand (cf. among others KWIATKOWSKA 2014).

${ }^{5}$ Investment value (individual) - the amount of money specified for each investor or group of investors who have clearly defined expectations and criteria for an investment and who intend to use the property for a specific investment purpose (KSWP 2). It can be accepted that the buyer's reservation price is equal to the specified investment value of the property for the buyer (cf. HENCLEWSKA 2000).

${ }^{6}$ Developers who direct their offer among others to investors buying apartments to let take this fact into account (cf. among others KWIATKOWSKA 2014).
} 
between the asking price and the market value estimated by the seller (YAVAS, YANG 1995). As mentioned earlier, in the case of a developer the asking price will also depend on other factors (cost of construction, marketing strategy, market position, strategic goals, etc.).

Asabere and Huffman demonstrate that if we determine the (theoretical) market value $\mathrm{P}_{\mathrm{T}}$, then: $\left(\mathrm{P}_{\mathrm{L}}\right.$ - $\left.\mathrm{P}_{\mathrm{A}}\right)$ is the "price concession" value of the seller and $\left(\mathrm{P}_{\mathrm{L}}-\mathrm{P}_{\mathrm{T}}\right)$ is the overestimation buffer. A situation where $\left(\mathrm{P}_{\mathrm{L}}-\mathrm{P}_{\mathrm{A}}\right)=\left(\mathrm{P}_{\mathrm{L}}-\mathrm{P}_{\mathrm{T}}\right)$ and thus $\mathrm{P}_{\mathrm{L}}=\mathrm{P}_{\mathrm{A}}$ occurs on competitive and effective markets, where, as a result of market forces, the equilibrium price is set at the level of market value. A situation where $\left(\mathrm{P}_{\mathrm{L}}\right.$ $\left.-\mathrm{P}_{\mathrm{A}}\right)>\left(\mathrm{P}_{\mathrm{L}}-\mathrm{P}_{\mathrm{T}}\right)$ and thus $\mathrm{P}_{\mathrm{L}}>\mathrm{P}_{\mathrm{T}}$ means there will be a bonus for the seller. This scenario takes place in the case of a so-called seller's market. The opposite situation, where $\left(\mathrm{P}_{\mathrm{L}}-\mathrm{P}_{\mathrm{A}}\right)<\left(\mathrm{P}_{\mathrm{L}}-\mathrm{P}_{\mathrm{T}}\right)$ and thus $\mathrm{P}_{\mathrm{L}}<$ $P_{A}$ indicates price concessions and is the result of a buyer's market (ASABERE, HUFFMAN 1993).

\section{Preferences of buyers as a factor affecting the investment value of apartments}

According to Stachura (STACHURA 2007), "the basis of the correct price decisions is product positioning. Placing the product in a selected segment can occur after determining consumer preferences and their purchasing power (...) consumers will readily accept the proposed price of a house or residence if the offered product will satisfy their needs in a material sense, as well as offer value in the form of satisfying communication throughout the transaction." Thus, the preferences of residential real estate buyers should be considered as a factor which shapes the investment value of the property. Because of this, the developer, intending to set an asking price, should first get to know the conscious and unconscious preferences of potential residence buyers. "Studying the preferences (...) of customers (...) can lead to learning their behaviors and is indispensable for undertaking segmentation and pricing decisions, and creating marketing and promotion conceptions. It is also a part of the informational system for marketing strategies (...)," (STACHURA 2007). In Poland, studies of buyer preferences are led by academic researchers (e.g. STACHURA 2011; STACHURA 2012) as well as commercial firms. It is worth noting, however, that in order for such analyses to be useful for the developer and enable undertaking decisions (e.g. regarding the architecture of the building), they should be detailed. To be more specific - they should concern especially the expected product and improved product according to Kotler's conception ${ }^{7}$ (KOTLER 1999), for it appears that on the residential real-estate market, the competitive battle is fought at the level of expectations and product improvements (cf. KOTLER 1999). Secondly, the developer should assess the advantages and disadvantages of the property for sale in light of these preferences, meaning that he should determine to what degree the offered property fulfills the preferences of the buyers on expected and expanded levels ${ }^{8}$. Thirdly, he should compare the property with the competition's products and on this basis correctly valuate the product at hand.

A useful tool for price positioning of real-estate is the price positioning matrix - a grid allowing for the determination of the place of the product on the market, analyzed in terms of two criteria: value and price (figure 2) (RUSKIN-BROWN 2009). In practice, however, this can prove quite difficult.

PRICE

\begin{tabular}{rl|c|c|c|} 
& \multicolumn{2}{c}{ low } & \multicolumn{1}{c}{ medium } & high \\
\cline { 3 - 5 } VALUE & high & Extraordinatory value & Penetration price & Premium price \\
\cline { 3 - 5 } medium & Solid value & Average price & Inflated price \\
\cline { 3 - 5 } & low & Low value & Skimming & Extortion \\
\cline { 3 - 5 } & & &
\end{tabular}

Fig. 2. Price positioning matrix. Source: RUSKIN-BROWN 2009.

\section{Pricing strategies of housing developers in Poland}

Two functions of the asking price can be indicated (ARNOLD 1999). The first is to attract as many potential buyers as possible. Usually, a lower asking price (assuming a lack of other differences, e.g. in advertising, characteristics of the property) will encourage more potential buyers to examine the property and set up an appointment with the seller. On the other hand, the asking price fulfills the

\footnotetext{
7 The expected product possesses the characteristics and conditions that the buyers intending to purchase the given product expect; the improved product is equipped with additional services or advantages which differentiate it from competitors' offers (KOTLER 1999).

${ }^{8}$ A description of the basic product and the improved (expanded) product with regards to residential real-estate can be found in Stachura (STACHURA 2007).
} 
function of a starting price - the base value in negotiations, which leads to the establishment of a transaction price. Therefore, a lower asking price can weaken the bargaining power of the seller. In accordance with these two functions of the asking price we can determine two radical pricing strategies utilized in the sale of houses or apartments (also observed in the case of Polish housing developers).

The first consists of establishing prices roughly equal to the estimated market value (thus equal to the expected transaction price). It is then a fixed price, disclosed and non-negotiable. In this case the customer can acquire the property at the price proposed by the seller, sometimes with a small discount, or can resign from the purchase. The second consists of establishing the asking price at a level decidedly higher than the estimated market value (and also decidedly higher than the expected transaction price) with a focus on individual price negotiations and the possibility of significant discounts (cf. MILLER, SKLARZ 1987).

Strategy 1. Setting the residence price at the level of estimated market value and treating it as nonnegotiable (or negotiable to a minimal degree) can turn out to be an effective strategy, especially if the developer valuates his product well and is able to justify the price to the potential buyer. The risks of this strategy are tied with the possibility of undervaluing the price (selling too cheaply) or overvaluing it (if the developer is not willing to negotiate, he will not sell). Advantages are the transparency of the offer, which the customer can appreciate, and a lower price than that presented by entities utilizing the second strategy. Transparency and lower cost can be a decisive factor in convincing the customer to arrange a meeting with the developer and examine the property as the first, which in turn, if the first impression is favorable, can induce a confirmation effect, discussed further in this article.

Strategy 2. The strategy of overpricing has an important advantage for the developer - it gives him the opportunity to achieve a higher price than the first strategy (even the maximum price, that the buyer is willing to pay). As Bucchianieri and Minson have noted, the buyer will negotiate to drive down the asking price until it reaches the level of the reservation price, which he is willing to pay for the property in question (BUCCHIANIERI, MINSON 2013).

As it appears, several potential factors of success of this strategy can be indicated on the foundation of behavioral economics 9 :

1) buyers are sometimes prone to treating price as an indicator of quality,

2) buyers unconsciously utilize the "anchoring and adjustment" heuristic,

3) buyers consciously or unconsciously use the category of "price range",

4) buyers are motivated by individual preferences,

5) buyers are subjected to a "confirmation bias", selective searching for and interpretation of information,

6) on the given market, there is a custom (practice) of negotiating prices (buyers expect the possibility of price negotiation).

Price as an indicator of quality. Price reliance is defined as the degree to which consumers rely on prices as an indicator of quality or value (MILLER, SKLARZ 1987). Miller and Sklarz point out studies in which it was demonstrated that: 1.) price is a weak indicator of value and is more tied in with marketing strategy, 2.) consumers rely on price as an indicator of better value ${ }^{10}, 3$.) buyers have a tendency to trust the honesty of sellers, expecting that a higher price results from the higher quality of the product or service, even if they cannot independently discern the difference between the product and its less expensive equivalent. As researchers have emphasized, the lack of transparency and heterogeneity which characterize the real-estate market can (at least theoretically) cause the buyer to consider the price as an indicator of quality.

The "anchoring and adjusting" heuristic. Manifests itself in the fact that: 1) consciously or unconsciously, the adopted reference value (anchor) affects the estimated values considerably and 2) estimated values based on the "anchor" are insufficiently corrected. Mussweiler et al. quote studies in which it was demonstrated that anchoring plays a significant role in the negotiation process. In several studies it was shown that the result of negotiation is strongly determined by the initial offer (MussweIler, STRACK, PFEIFFER 2000). It is worth noting that in the case of transactions on the realestate market a situation may also occur (at least theoretically) where the buyer accepts the asking price as the anchor. In such a case, the higher asking price of the house or residence can result in a

9 Their choice is the result of the author's own reflection.

10 These studies did not concern real-estate. 
higher transaction price. The results of a few studies which concern the phenomenon of anchoring in the case of valuation and the sale of houses have been presented below.

Miller and Sklarz conducted research on a sample of over 600 observations (similar condominiums in Honolulu), under conditions of stable market prices and low inflation in the years 1984-1985. On the basis of transaction costs and estimated market value, obtained by the use of a multiple regression model, they determined that: 1) aside from a few exceptions, the asking price was higher than the transaction price; 2) the time-frame of selling was longer when the asking price was higher than the predicted selling price (market value); 3) an increase in the relationship of the asking price to the predicted selling price was not reflected in a proportional increase of the relationship between the transaction price to the predicted price (an increase in the overestimation of the asking price - in relation to the predicted price - was accompanied by a decreased influence of the asking price on the transaction price); 4) in the case of an "overestimated" asking price, the standard deviation of the difference between the transaction price and the predicted price was decidedly higher than in the "not over-estimated" asking price range, which can indicate the possibility of selling the property at an "inflated" price. In their conclusions the researchers recommend, as a pricing strategy, setting the asking price at a least equal to (or higher) than the average price of similar properties. They emphasize that on such an imperfect market as the real-estate market, value is never known with certainty, so a certain degree of inflation of the asking price enables a higher transaction price to be achieved (MILLER, SKLARZ 1987).

Northcraft and Neale (NORTHCRAFT, NEALE 1987) investigated the use of a decisional heuristic "anchoring-and-adjustment" on the real estate market using an experimental technique ${ }^{11}$. In their study, amateurs and experts (professional real estate brokers) were asked to estimate the values of properties. They were given listing prices (different for each of the groups) and other information about houses and the local housing market. The experiment demonstrated that the magnitude of listing price information significantly impacts the valuations of both amateurs and experts. The researchers also noted that amateurs appeared more aware of the role that listing price plays in their judgments; the decision checklists flatly denied their use of listing price in the valuation process ${ }^{12}$. The proposed conclusions were: (1) experts are susceptible to decision bias, and (2) experts are less likely than amateurs to admit to (or perhaps understand) their use of heuristics in producing biased judgments. The results revealed that, as Northcraft and Neal emphasize, the seller's listing price might serve as an anchor in the bidding process.

Bucchianeri and Minson based their study on data concerning all single-family home sales in Delaware, New Jersey and Pennsylvania between January 2005 and April 2009 (over 14,000 transactions) (BUCCHIANERI, MINSON 2013). They found that higher listing prices are effectively associated with higher selling prices, consistent with anchoring. To identify the effect of overpricing a home, they calculated the expected sale prices based on objective characteristics if listing behaviors had no impact. To proxy the expected sale price based on objective characteristics they conducted a hedonic sale price regression ${ }^{13}$ and also calculated the component of the previous sale price that hedonic regression did not predict (due to qualities that are important to buyers but unobserved by the econometrician). In the study they showed, among others, that: 1) over-pricing is positively correlated to the log sale price, while under-pricing is negatively correlated to it; 2 ) the extent to which over- or under-pricing relates to the log sale price increases with the extent of over- or under-pricing ${ }^{14}$; 3) greater listing price heterogeneity in a given area significantly decreases the relationship between pricing strategies and transaction price.

\footnotetext{
11 Experimental economics is an established area of study in mainstream economics. Experiments allow to study empirical regularities in domains for which theory is not developed enough and help to test different theories and predictions (See: ONG et al., p. 156).

12 Only $24 \%$ in the first experiment and $19 \%$ in the second admitted to taking this into account in the valuation of asking price (in the case of amateurs, respectively $56.2 \%$ and $37 \%$ admitted to it).

13 Using 331,541 home sales from a data set of all MLS transactions for Delaware, New Jersey and Pennsylvania from January 2005 to April 2009.

14 The average overpricing between 10 and $20 \%$ leads to an increase in the sale price of $0.05-0.07 \%$ in the sale price for each $10 \%$ increase in the expected price. Instead for a home that was listed $20 \%$ or higher than other homes in the neighborhood, the additional increase from overpricing for each $10 \%$ increase in the expected sale price amounts to $0.16-0.22 \%$ of the sale price.
} 
Horowitz (HoROWITZ 1992) estimated two models of predicting the transaction price. The first one was an econometric model ${ }^{15}$ based on the offer price and the observed attributes of the house as explanatory variables (also serving to predict sellers' reservation price). The second one was a hedonic price regression model. Interestingly, he demonstrated that the predictions of sale prices obtained from the first model were considerably more accurate than those obtained from standard hedonic price regression. The model of sale prices based on listing prices and observed attributes explained $98 \%$ of the variation in observed sale prices. The author calculated the root-mean-square error in the prediction of the sale price on the basis of the list price - 2,960 USD. Using the hedonic price regression model of the sale price, the researcher received a significantly higher RMS prediction error (10,380 USD).

Accepted price range. According to marketing theory, buyers are willing to accept a price which falls within a certain range (cf. MONROE 1971). In order to establish the minimum and maximum price accepted by the buyer of a given product, various price tests are used. In the classical price test respondents indicated four price levels, which designate the product as: 1) too cheap (that is, of dubious quality); 2) cheap; 3) expensive; 4) too expensive to acquire (WANIOWSKI 2003). An example of price testing (and the range of accepted prices) on the residential real-estate market is presented by Stachura (STACHURA 2007). Here we can acknowledge that the buyer demonstrates certain elasticity when it comes to the price he would be willing to pay for a property.

Individual preferences. The potential buyer valuates the residence (and makes a decision) according to his own preferences and needs. These can differ from the preferences of the average buyer. In such a case, the individual value of the apartment can significantly surpass the market value (and the asking price based on market value). Thus, the developer can in fact achieve this price by setting a higher asking price.

Confirmation bias. Confirmation bias is based on the tendency to search out and assign excessive importance to information which confirms our initial impressions, opinions, or preferences, while at the same time overlooking or disregarding information which refutes them. In this way, it strengthens distortions caused by the anchoring effect (BELSKY, GILOVICH 2010). People may exhibit a tendency to supply a greater number of arguments which are consistent, rather than inconsistent, with the anchor, e.g. the asking price. In searching for confirmation of a high price, the potential buyer of a property with a high asking price may pay more attention to an attractive location or a beautiful view from the window than obsolete installations or stairs in a state of devastation (BUCCHIANERI, MINSON 2013).

Custom. If, on the given market, a custom of negotiating prices has developed, or the majority of developers have adopted such tactics under certain market conditions (recession), or if the property is atypical, then the buyer can expect in advance that the asking price is higher than the price at which the seller is willing to sell the property. The developer should therefore take into account such buyer expectations when setting the asking price.

The use of an overpricing strategy is associated with risk for the developer. Firstly, the customer will not contact the developer if he considers the asking price prohibitive (deviating too much from the maximum price the buyer is willing to pay). Thus the main disadvantage of this strategy is the risk of losing potential customers (unaware of the potential for negotiation and lowering the asking price). Secondly, if the given developer is the only one on the local market who lowers asking prices through overt discounts, the potential buyer can assume that the developer has financial problems or the properties are defective (they possess hidden flaws). He may consider the purchase of the property to be saddled with additional risks. Thirdly, the customer may become aggravated or nervous during the negotiations, and not go through with the purchase.

It is also worth noting the strategy of not disclosing the asking price, used by developers on the Polish real estate market. It can rely on providing information in the announcement that the price is negotiable, or that the details of the offer will be revealed at the meeting, or on providing only the price of the cheapest unit in the given developer's investment ("prices starting at..."). An extreme case of the non-disclosure of asking price is the strategy of "Suggest your own price" (the customer should first propose a price). By using this strategy, the developer hopes that, firstly, the buyer will, for psychological reasons, be more willing to complete the transaction, and secondly, that the purchaser

15 Based on data of 1,196 houses sold in Baltimore City and County, Maryland, USA, during 1978. The data included the sale price, list price, and time from listing to sale of each house as well as 46 attributes of houses and their neighborhoods. 
will propose a higher price than the reservation price at which the developer is willing to sell the property (www.wgn.pl). The transaction price could be much higher than the market price, as it would result from the high investment value for that buyer. Too high a price given by the buyer can also be a result of his lack of knowledge of the real-estate market. A further advantage of price nondisclosure, according to developers, is the possibility of being contacted by customers who may have limited financial means (and the price presented in the offer for a given property may be too high). The developer would then propose a different, cheaper, property. The lack of an asking price thus often serves as encouragement for the customer to contact the developer - by providing a phone number, making a phone call, or sending an email (www.biznes.pl). According to developers, giving no price in the advertisement is also intended to provide the buyer with the sense that the transaction is unique. As Skoczen noticed earlier, "this method of shaping the relationship with the customer was characteristic for (...) the most elite and most expensive investments, and nowadays is becoming more and more visible in the upper-class segment or popular segment" (www.biznes.pl). Another reason for "concealing" the price (indicated by the developers as the most important) is preventing the risk that the customer will be guided solely by price during property selection and will not take into account better functionality, surroundings, quality of finishing, etc. (www.marketingnieruchomosci.pl).

On the other hand, the strategy of the non-disclosure of prices has potential disadvantages. Firstly, the lack of transparency of the offer with regards to price can cause the potential buyer to consider it dishonest ("price manipulation") and unfair (different prices depending on the skills of the negotiators). Secondly, the potential buyer can assume that if the price is not provided in the advertisement, then it will probably too high; in such a case a customer, who would have been able to afford an apartment (according to the seller's reservation price) might chose not to call because of overestimating the price at which the developer would be willing to sell the property. It seems, however, that the aforementioned disadvantages will not be important if all developers use the same strategy and it becomes an accepted custom on the real-estate market.

\section{Conclusion}

Based on information obtained from real estate developers, it can be concluded that these same developers utilize various pricing strategies for different investments, depending on the market situation, the size of their competition in the given segment, and the standard of the property. Smaller and "un-advertised" companies see the need to lower asking prices in comparison to the offers presented by larger, better-known companies. Developers pay attention to the price levels of their competitors. Cooperation with a real estate appraiser when setting the asking price is not the rule.

To summarize the discussion, it should once again be emphasized that pricing strategy composes a part of marketing strategy, and that price is one of the four elements of the marketing-mix, thus searching for the optimal pricing strategy without taking into account the remaining elements is incorrect. Furthermore, it should be recognized that the developer should not confine himself solely to cost methods when setting the asking price, but should also take into account methods based on the prices set by competitors and demand methods (including those based on the value of the property for the customer). Certainly, in order for asking price to be determined accurately, one should acknowledge the importance of knowledge regarding property buyers' preferences as well as the ability to determine to what degree the offered property fulfills the preferences of buyers at the expectation level and expanded levels. Some familiarity with elements of psychology and behavioral economics also do not seem to be without merit, especially with regards to the real estate buyers' treatment of prices as indicative of quality, their use of the "anchoring and adjustment" heuristic, and the possibility of the occurrence of a confirmation bias.

\section{References}

ARnold M. A., 1999, Search, Bargaining and Optimal Asking Prices, Real Estate Economics, vol. 27, issue 3

Asabere P. K., Huffman F. E., 1993, Price Concessions, Time on the Market, and the Actual Sale Price of Homes, Journal of Real Estate Finance and Economic, vol. 6

BELSKY G., GILOVICH T., 2010, Dlaczego madrzy ludzie popetniaja gtupstwa finansowe?(Why Smart People Make Big Money Mistakes and How to Correct Them: Lessons from the Life-Changing Science of Behavioral Economics) Wyd. Helion, Gliwice 
BuCChiAneri G.W., Minson J.A., 2013, A homeowner's dilemma: Anchoring in residential real estate transactions, Journal of Economic Behavior \& Organization, vol. 89

HENCLEWSKA L., 2000, Wartość rynkowa, a wartość inwestycyjna nieruchomości, (Market Value and Investment Value of Real Estate), Nieruchomości C. H. Beck, nr 8

Horowitz J. L., 1992, The Role Of The List Price In Housing Markets: Theory And An Econometric Model, Journal Of Applied Econometrics, vol. 7

KARASIEWICZ G., 1997, Marketingowe strategie cen (Marketing Pricing Strategy), PWE, Warszawa

KWIATKOWSKA M., Ceny mieszkań: Deweloperzy podnosza ceny ostrożnie. Nie chca stracić klientów, Gazeta Prawna z dnia 13.01.2014 (Prices of apartments: Developers raise prices carefully. Do not want to lose customers, The Legal Newspaper, dated13.01.2014)

Krajowy Standard Wyceny Podstawowy Nr 2 (KSWP 2), Powszechne Krajowe Zasady Wyceny (National Standard Valuation Basic No 2, Common National Valuation Principles)

KOTLER P. , 1999, Marketing. Analiza, planowanie, wdrażanie i kontrola (Marketing Management. Analysis, Planning, Implementation and Control), Wyd. FELBERG SJA, Warszawa

Miller N. G, SKLARZ M. A., 1987, Pricing Strategies and Residential Property Selling Prices, Journal of Real Estate Research, Volume 2, Number 1

Mussweiler T., STRACK F., PfEIFFER T., 2000, Overcoming the Inevitable Anchoring Effect: Considering the Opposite Compensates for Selective Accessibility, Personality And Social Psychology Bulletin, Vol. 26 No. 9

Monroe Kent B., 1971, Measuring Price Thresholds by Psychophysics and Latitudes of Acceptance, Journal of Marketing Research, 8 (November)

NorthCraft, G.B., NeAle M. A., 1987, Experts, Amateurs, and Real Estate: An Anchoring-and-Adjustment Perspective, Organizational Behavior and Human Decision Processes, 39

ONG S.E., CHENG F.J., BOON B., SING T.F., 2003, Oligopolistic bidding and pricing in real estate development. Experimental evidence, Journal of Property Investment \& Finance, vol. 21, nr 2

RUSKIN-BROWN I., 2009, Skuteczna polityka cenowa. Aspekty praktyczne (Practical Pricing for Results), Oficyna a Wolters Kluwer business, Kraków

STACHURA E., 2007, Marketing na rynku nieruchomości (Marketing on Real Estate Market), PWE, Warszawa

STACHURA E., 2012, Kształtowanie architektury domów i mieszkań z wykorzystaniem wyników badań preferencji mieszkaniowych Polaków, Studia i Materiały Towarzystwa Naukowego Nieruchomości, (Architectural Design Of Houses And Flats According To The Results Of Consumer's Housing Preferences Research, Journal Of The Polish Real Estate Scientific Society), vol. 20, nr 3, 2012, Olsztyn

STACHURA E., 2011, Badania rynku nieruchomości a proces projektowania zespołów mieszkaniowych $i$ budynków mieszkalnych, Inwestycje i nieruchomości. Wyzwania XXI w., red. Nalepka A., Wyd. UE $\mathrm{w}$ Krakowie (Research on real estate market and the process of designing housing complexes and residential buildings, Investments and Real Estate. The Challenges of the XXI Century, ed. Nalepka A.)

Ustawa o gospodarce nieruchomościami, Dz. U. z 1997 nr 115 poz. 741, z późn. zm. (Act of 21 August 1997 on the Real Estate Management, Journal of Laws, 1997, No. 115, item 741, as amended)

WANIOWSKI P., 2003, Strategie cenowe (Pricing Strategies), PWE, Warszawa

www.biznes.pl/magazyny/nieruchomosci/dewelopment/dlaczego-wielu-deweloperow-nie-podajecen-mieszkan,5210925,magazyn-detal.html, 7.08. 2012

www.marketingnieruchomosci.pl/index.php/promocja/z-cena-czy-bez-ceny-oto-jest-pytanie 25.01.2010

www.wgn.pl/i/a,1,4692,0,pl,-zaproponuj-swoja-cene-nowy-pomysl-deweloperow-na-przyciagnieciekupujacych.html

Yavaş A., YAnG S., 1995, The Strategic Role of Listing Price in Marketing Real Estate: Theory and Evidence, Real Estate Economics, vol. 23, issue 3 